\title{
Quality of Life among Widows
}

\author{
Dr. Chandrakant Jamadar ${ }^{1}$, Dr. S. P. Melkeri ${ }^{2}$, Dr. Ashok Holkar ${ }^{3}$
}

\section{ABSTRACT}

This paper gives an overview of the current status of widows quality of life for assessment of widows quality of life scale used reliable and validated scale by B.L. Dubey, Padma Dwivedi, S.K. Verma Social Scientist, post Graduate medical Institute, Chandigarh ,India. Test was administered to a random sample 200 in different age, domicile and, literacy group widows from Mysore. For analysis used relevant statistical tool like mean, standard deviation t-test. The findings of the study reflects that , the working widows have better quality of life than the others, and another important findings that those are literate they also have better quality of life than the illiterate widows.

Keywords: Widows, Quality Of Life, Occupation And Society.

A widow is a woman whose husband has died, while a widower is a man in that situation. The state of having lost one's spouse to death is termed widowhood. These terms are not applied to a person after he or she becomes divorced from their former spouse, though they may sometimes be used after the former spouse has died.

This term "widowhood" can be used for either sex, at least according to some dictionaries, but the word widower hood is also listed in some dictionaries. Occasionally, the word viduity is used. The adjective form for either sex is widowed.

The treatment of widows around the world varies, but unequal benefits and treatment generally received by widows compared to those received by widowers globally has spurred an interest in the issue by human right activist. In societies where the husband is the sole provider, his death can leave his family destitute. The tendency for women generally to outlive men can compound this, since men in many societies marry women younger than themselves. In some patriarchal societies, widows may maintain economic independence. A woman would carry on her spouse's business and be accorded certain rights, such as entering guilds. More recently, widows of political figures have been among the first women elected to high office in many countries, such as Smt. Shanta Patil from Gulbarga, Karnataka.

\footnotetext{
${ }_{1}^{1}$ Asst. Professor, Post Graduate Department of Studies in Psychology, Maharani's College for Women, Mysore.

${ }^{2}$ Professor and Chairman, Department of Psychology, Gulbarga University Gulbarga ,Karnataka.

${ }^{3}$ Asst. Professor, Government Arts First Grade College, Bangalore, Karnataka

*Responding Author

(C) 2015 I C Jamadar, S Melkeri, A Holkar; licensee IJIP. This is an Open Access Research distributed under the terms of the Creative Commons Attribution License (http://creativecommons.org/licenses/by/2.0), which permits unrestricted use, distribution, and reproduction in any Medium, provided the original work is properly cited.
} 


\section{Quality of Life among Widows}

Widows in India have a pronoun problem. The estimated 40 million women widows in the country go from being called "she" to "it" when they lose their husbands. They become "desexed" creatures.

Clearly, it's more than a problem of language, although that discrimination goes further, with epithets such as "husband eater" used against them. In the northern Indian state of Punjab, a widow is referred to as randi, which means "prostitute" in Punjabi. In this region, they usually arrange for the widow to marry her deceased husband's brother because being owned by a man is a way to avoid being raped.

"Widowhood is a state of social death, even among the higher castes," says Mohini Giri, a veteran activist in the fight for women's rights who was nominated for the Nobel Peace Prize in 2005. She is also the director of the Chennai-based social work nonprofit organization Guild for Service. "Widows are still accused of being responsible for their husband's death, and they are expected to have a spiritual life with many restrictions which affects them both physically and psychologically." A widow prays in an ashram in Vrindavan. Women are often forced into prostitution by corrupt heads of such ashrams. (Sara Barerra)

Although widows today are not forced to die in ritual sati (burning themselves on their husband's funeral pyre), they are still generally expected to mourn until the end of their lives. the Hindu progenitor of mankind: "A virtuous wife is one who after the death of her husband constantly remains chaste and reaches heaven though she has no son.”

Whether young or old, widowed women leave behind their colourful saris, part with their jewelry, and even shave their heads, if they are in the more conservative Hindu traditions. All of this is designed so as not to encourage male sexual desire, according to Meera Khanna, a trustee of the New Delhi-based Women's Initiative for Peace in South Asia, and a contributor to of a book called Living death : Trauma widowhood in India.

“The widow is 'uglified' to deprive her of the core of her femininity," writes Khanna. "It is an act symbolic of castration. She is deprived of the red dot between her eyebrows that proclaims her sexual energy."

Widows seem to follow rules based on tradition because they have internalized them. They keep doing what other widows did without asking, resigned to a kind of fate- such as placing restrictions on their own diets. Orthodox Hindus believe that onions, garlic, pickles, potatoes, and fish fuel sexual passions by stimulating the blood, but these are the same foods necessary to avoid malnutrition or even death. For India as a whole, mortality rates are 85 percent higher among widows than among married women, according to research by the Guild for Service. In much of Indian society-across caste and religion-a widow is often perceived by family members to be a burden and sexually threatening toward marriages. 


\section{Quality of Life among Widows}

A widow is a woman whose spouse has died, while a widower is a man in that situation. The state of having lost one's spouse to death is termed widowhood. These terms are generally not applied to a person after he or she becomes divorced from their former spouse. Widow This term "widowhood" can be used for either sex, at least according to some dictionaries, but the word widower hood is also listed in some dictionaries. Occasionally, the word avidity is used. The adjective form for either sex is widowed.

The treatment of widows around the world varies, but unequal benefits and treatment generally received by widows compared to those received by widowers globally has spurred an interest in the issue by human rights activists

Every country has widows. As India has a population as well as 100 nations, it is 100 times more than other countries. In addition to poverty, the unavailability of medicine, the increase in alcoholism, terrorism and natural calamities like Tsunami's, have caused many deaths. When we see the number of widows in India it is unbelievable.

In India, people don't like a widow to cross the path in front of them when they are beginning a journey on foot, bicycle or car. It is considered bad luck and a sign of future failure. Unfortunately, most Indian cultures consider widows as a sign of misfortune and bad luck.

. "When [a woman] loses her husband and becomes a widow, she loses her identity. A woman deprived, abandoned, malnourished will naturally have a high mortality rate."

For the more than 40 million widows in India - 10\% of the country's female population - life is what some have described as "living sati", a reference to the now the prohibited practice of widow burning. Some are as young as 10 years old and are forced to spend the rest of their days in seclusion or earning a living through prostitution.

Only $28 \%$ of the widows in India are eligible for pensions, and of those, less than $11 \%$ actually receive their entitled payments. If a woman is not financially independent, she is at the mercy of her in-laws and her parents. And if they do not have the will or resources to take care of her and her children, she will be treated like an "untouchable". Financial aid is crucial to widows wanting to lead a self-sufficient life, but the government has failed to provide it.

Many of the 16,000 widows in Vrindavan have no choice but to beg in the streets. Traditionally, widows are only allowed one meal a day and renounce all earthly pleasures. However, Giri provides an alternative refuge and "ashram" for destitute widows in the state of West Bengal. "We break away from the traditional norms of widows being given one meal a day and not being allowed to have meat or certain foods such as garlic and onions."

Orthodox Hindus believe that both meat and certain vegetables have pulses that stimulate blood and are therefore impure. It is no wonder that deaths as a result of malnutrition are $85 \%$ higher 


\section{Quality of Life among Widows}

among widows than married women, according to the Global Ministries Foundation. They are even expected to fast several times a month, sometimes eating nothing but fruit for days on end. In the last 20 years, Giri has come to believe that "traditions are manmade and are prevalent in society due to its widespread acceptance in the social milieu ... a patriarchal Brahaminical society has enforced wrong values in society towards widows". Nevertheless, trying to change the taboos surrounding remarriage and widows' conduct is only possible if the government enforces education to explain their harmful effects. The states of Andhra Pradesh and West Bengal have the highest percentage of widows in India, primarily because of objections to remarriage with a recent report conducted by the national commission of women stating that $74 \%$ of destitute widows live in West Bengal; there is a clear indication that implementing legislation has been unsuccessful. "Widowhood is not a priority within the government. It is only now that we are pushing the issue with the government, the planning commission and also at the United Nations." However, the recent 33\% quota for women at grassroots political level is a source of great strength for the advocacy of women's rights and enough to see a perceptible change. Giri has established many pioneering shelters for widows that aim to enhance their skills and make them more economically independent. But to make a difference in the longer term, traditional values will have to change.

A widow must wear only white series and fully cover her face. The widows must also stay aloof and alone from the ordinary family, and should not show their face to the ordinary public. There are also families who blame the widow for the death of her husband, saying that her bad luck has killed the husband and made the children orphans. For instance, if a husband has AIDS and dies, he leaves the widow and her family victims of that disease, by no mistake of their own, but she is blame WIDOWS in India face multiple, often conflicting, and social expectations. Their status is defined by a complex and diverse host of religion-based personal codes, regional, jati, kinde based customs, and government laws. The condition of widows in different groups, cultural areas and classes are therefore vastly different. A new anthology, Widows in India: Social Neglect and Public Action, assembles papers produced for a conference on this topic held in 1994 in Bangalore.

\section{Quality of life}

"The problem of widows - and especially of child widows - was largely a prerogative of the higher Hindu castes among whom child marriage was practiced and remarriage prohibited. Irrevocably, eternally married as a mere child, the death of the husband she had perhaps never known left the wife a widow, an inauspicious being whose sins in a previous life had deprived her of her husband, and her parents-in-law of their son, in this one. Doomed to a life of prayer, fasting, and drudgery, unwelcomes at the celebrations and auspicious occasions that are so much a part of Hindu family and community life, her lot was scarcely to be envied. 


\section{Quality of Life among Widows}

On the other hand, the lower, particularly Sudra, castes and the (so-called) 'Un-touchable'—who represented approximately 80 per cent of the Hindu population-neither practiced child marriage nor prohibited the remarriage of widows."

Old age is the period of decline and closing period of life. According to Elizabeth Hurlock 1981) Old age has been classified as early old age and advanced old age [70-end of life].According to Sowmiya (2012) Ageing is a normal, inevitable, biological and universal reality. According to WHO (1996)“Quality of life is defined a individual's perceptions of their position in the context of the value system in which they live and in relation to their goals, expectation, standards and concerns”. Quality of life is very imperative for elderly who are widowed, divorced and separated to enhance their wellbeing. Inclusion and rehabilitation are major concern which should be rendered to promote the standard of life of WDS. It is operational zed in this study that neglected institutional women are Widows, divorced and separated. Widows, divorced and separated are unacknowledged, invisible, not main stream individuals. separated widows state is magnified as negative life event which is traumatic making them to go in the paths of remorse and aloofness which is dehumanising. There are vivid reasons to be victims of widowhood, divorced and separated whereby they are neglected due to deviant myths and misconceptions concerning WDS. The widowhood in elderly is a state of elderly women who has lost her husband by death and has not married again It may be granted if the spouse is mentally incompetent. Separated is couple intentionally or on-intentionally bonded in marriage not living together? The common problems of WDS are economic hardship, higher rates of common mental health problems, adjustment problems, loneliness, phobias to live alone, social stigma, socialisolation and neglect, low self-esteem, widows remarriage is highly discourage in high class, poor nutrition, compelled for prostitution, draining in poverty, indulging in begging, inadequate shelter, domestic violence among families members. Prone to rape, poor accessibility of health care, migration, neglected by members of justice providers , According to the Times of to India (2012) highlights that Tamilnadu has highest percentage [8.8\%] of widows, divorced and separated. The percentage of WDS females was almost three times than of men [29\%against 10\%]. Mohammed Tagh Sheykshin [2006] found that widowhood leads them to bereavement, readjustment, low social status entitled as vulnerable section of society. Giles [2013] says on impact of divorce women that it leads to financial and emotion distress which curbs the quality of life. So it is obligatory to cater to the rehabilitation needs of WDS who has enormous negative implications.

\section{METHODOLOGY}

Statement of the problem: To study on quality of life among widows.

\section{Objectives of the study:}

- To study the quality of life among widows.

- To understand the rural and urban widows in their quality of life.

- To assess the literate and illiterate widows quality of life.

- To understand the quality of life of widows is their different age group. 


\section{Quality of Life among Widows}

\section{Hypothesis}

- There is a significant difference in quality of life among widows.

- There is significant differences between rural and urban widows are their quality of life.

- There is a significant difference between literate and illiterate is their quality of life among widows.

- There is a significant differences in different age group widows his their quality of life.

- There is a significant difference between working and nonworking widows is their quality of life.

\section{Variable}

Dependent variable: quality of life

Independent variable: widows

Sample size: A sample of 200 widows will be taken for the study.

\begin{tabular}{|l|l|}
\hline Widows & $\mathbf{2 0 0}$ sample \\
\hline Literate & 25 \\
\hline Illiterate & 25 \\
\hline Rural & 25 \\
\hline Urban & 25 \\
\hline Age group 20-40 & 25 \\
\hline 41 and above & 25 \\
\hline Working widows & 25 \\
\hline Nonworking widows & 25 \\
\hline Total & 200 \\
\hline
\end{tabular}

The sample consist of 200 frames Literate, illiterate rural and urban and different age group of widows from Mysore district. The sample collected sand method.

Design: Quasi experimental designs.

I'm going to do a psychological experiment where I make people different ages and then see how they react to loud noises. Well, I'd like to. Unfortunately, even with our advanced quantum physics and computers, we cannot reverse or control age like that. Psychological researchers are forced to work around the issue.

Because we can't reverse someone's age, we have to work with people who are already that age. But we miss some things in the process. But I'm getting ahead of myself.

A true experiment has one main component - randomly assigned groups. This translates to every participant having an equal chance of being in the experimental group where they are subject to a manipulation or the control group where they are not manipulated. 


\section{Quality of Life among Widows}

A quasi-experiment is simply defined as not a true experiment. Since the main component of a true experiment is randomly assigned groups, this means a quasi-experiment does not have randomly assigned groups. Why are randomly assigned groups so important since they are the only difference between quasi-experimental and true experimental?

When performing an experiment, a researcher is attempting to demonstrate that variable A influences or causes variable B to do something. They want to demonstrate cause and effect. Random assignment helps ensure that there is no pre-existing condition that will influence the variables and mess up the results.

A silly example would be something like 'Does chemical X1 cause blindness?' If you accidentally put all of the people wearing glasses in the condition where you spray X1 in someone's face, then your results are going to be skewed. This is an extreme and overly simplistic example, but it is demonstrating why normally an experimenter wants to randomly assign people into different groups. Let's look at some more realistic and typical quasiexperiments in psychology.

Materials : Quality of life scale-R(QLS-R)B.L. Dubey, Padma Dwivedi, S.K. Verma Social Scientist, post Graduate medical Institute, Chandigarh ,India. One of the relatively newer concepts in the field of organizational behavior is the quality of life. It has not received due care and attention so far, has it deservers. There is a board agreement, however that quality of life, general satisfaction level including job satisfactions and health, particularly mental health, are all important and inter-related concepts and need to be studied. They are all, directly or indirectly, related to the healthy growth of industry in a country and it is output in the long run. Although, all these are inter-related, they are not identical; rather they may be complimentary to each other. While some work as been done in the other areas, quality of life had been a neglected area it is now receiving some attention and is likely to be given it is proper place in times to come. It is particularly related to the aspects of positive mental health, which is more than the mere absence of ill-health and needs to be studied in it is own right.

Initial pool of items: This scale consists of 20 items. Reviewing th related literature, Maslow hierarchy of needs and factors of quality of life as suggested by verma (1986), a large number of items were selected/ constructed. The preliminary form of the scale consisted of 20 items. This preliminary form of the quality of life scale was given to industrial psychologists, sociologist and business executives for there opinion/modifications/ corrections, if any, required. After suitable modification, the first form of quality of life scale consisted 29 items with Likert (1932) types scoring systems consisting of 5 categories of agreement- disagreement.

Scoring: As mentioned earlier, the Liket type scoring systems consisting 5 categories of agreement- disagreement was applied to each item of final form of quality of life scale. The scoring weights for each item ranges from 1 to5 (strongly disagree to strongly agree 1 to5); with 


\section{Quality of Life among Widows}

the range of possible total scores from 24-120. Higher score indicates better quality of life (Items 2, 5, 23 are scored in reverse direction ); with the average score 72 and more, as better quality of life score,

Statistical analysis: Statistical techniques used for analysis. the researcher after collecting the data, the data were edited and coded. The data were then analyzed using various statistical tools like, mean SD and t-test.

ANALYSIS OF RESULTS

Table No.1.Mean,SD and t-value of quality of life of widows in literate and illiterate.

\begin{tabular}{|l|l|l|}
\hline Group & Literate & Illiterate \\
\hline Mean & 70.32 & 54.68 \\
\hline SD & 5.18 & 7.54 \\
\hline $\mathbf{N}$ & 25 & 25 \\
\hline t-value & \multicolumn{2}{|c|}{8.5474} \\
\hline p-value & \multicolumn{2}{|c|}{0.0001} \\
\hline
\end{tabular}

The above table shows that the Mean, SD, and t- value of widows in their quality of life, Literate and illiterate. Literate widows Mean and SD is 70.32 and 5.18 is higher than the illiterate widows is 54.68 and 7.54 respectively. The literate widow's score indicates that, they have better quality of life of than the illiterate widows. The calculate t- value is 8.54.it is significant 0.0001 level. Therefore, the formulated hypothesis is that, "there is significant differences between literate and illiterate widows in these" quality of life. Hence the formulated hypothesis is accepted. Related to this research many results have found. But" major research mentioned here. According to "Archana Patkar (she conducted research on) Socio-economic status and female literacy in India. It seems as if the universally acclaimed need for literacy has recently re-gained currency in India, justifying enormous investment in areas traditionally scorned for their low rate of return. The focus on increased enrolment, retention and achievement in primary education, in conjunction with feverish Total Literacy Campaigns conducted by the Government of India (GOI), may be credited with steering the spotlight away from more pressing structural problems such as the deeply ingrained gender bias at all levels of the education-employment matrix and the inherently gendered nature of the ideological framework underlying educational provision in India.

Seldom questioned is the value and relevance of the kind of literacy being advocated or the logic behind the slogan 'basic education as a basic human need'. It can be argued that churning out batches of literate women does not guarantee the articulation of their needs or their participation in planning and decision making. This paper argues that, divorced from other areas such as women's low socio-economic status, labour market inequalities and legal bias, literacy 
programmes are a relatively inexpensive and politically expedient palliative in their present limited form.

Table No.2.Mean, SD and t-value of quality of life of widows in Rural and Urban.

\begin{tabular}{|l|l|l|}
\hline Group & Rural & Urban \\
\hline Mean & 54.60 & 65.04 \\
\hline SD & 6.29 & 6.37 \\
\hline N & 25 & 25 \\
\hline t-value & \multicolumn{2}{|c|}{5.8316} \\
\hline p-value & \multicolumn{2}{|c|}{0.0001} \\
\hline
\end{tabular}

The above table shows that, the Mean, SD, and t- value of widows in their quality of life, Rural and Urban. Rural widows Mean and SD is 54.60 and 6.29 is higher than the Urban widows is 65.05 and 7.6.37 respectively. The rural widows score indicates that, they have better quality of life of than the urban widows. The calculate t- value is 5.8316.it is significant 0.0001 level. Therefore, the formulated hypothesis is that, "there is significant differences between Rural and Urban widows in these" quality of life Hence the formulated hypothesis is accepted. Related to this research many results have found "but major research mentioned here. According to “KAREN L HORNUNG” Loneliness among older Urban Widows “The purpose of this study was to determine the extent of loneliness among older urban widows in relation to seventeen social and demographic variables. The variables examined were: age, length of marriage, length of widowhood, education, household companion, frequency of telephoning, organizational activity, sufficiency of contact with a confidant, satisfaction with visiting patterns of relatives and friends, confinement, self-rated health, occupation, income, transportation, satisfaction with housing, feelings about the past year, and time spent alone. $\wedge$ The data were obtained by use of the Loneliness Questionnaire for Older Widows (LQ-OW) from a random sample of 80 older urban widows in Lincoln, Nebraska. The LQ-OW was adapted from the "Loneliness Questionnaire" (Woodward, 1967). The LQ-OW contained specific items related to the variables, questions on loneliness, and the Loneliness Inventory. The inventory included seventyseven questions requiring the participant to indicate under what circumstances she experienced loneliness. Responses of each interviewee to the Loneliness Inventory were analyzed to derive a loneliness score, ranging from zero to five. $\wedge$ The Statistical Package for the Social Sciences (SPSS) was used to analyze the data. Mean loneliness scores and standard deviations were determined for each of the categories within each of the seventeen variables. To test for significant differences in the mean loneliness scores within the various categories of each of the variables, one-way analysis of variance was employed. If a significant difference was detected, the Scheffe test of multiple comparisons was applied to determine which groups were contributing to the significance. The level of significance chosen was p (LESSTHEQ) .05 for the one-way analysis of variance, and p (LESSTHEQ) .10 for the Scheffe test.^ Findings of the 


\section{Quality of Life among Widows}

study included: (1) The mean loneliness score of 1.03 for the widows interviewed revealed that, as a group, these women were not found to be lonely. A comparison of the mean loneliness scores of the thirteen populations studied as part of the Loneliness Research Project at the University of Nebraska - Lincoln revealed that older urban widows reported more loneliness than elderly (Woodward, 1971) or elderly in homes for the elderly (Wythers, 1974), but reported less loneliness than all the other groups studied. Those previously studied groups included: young adults (Seevers, 1972; Swanson, 1971), adolescents (Otto, 1973; Gladbach, 1976), housewives (Visser, 1971), divorced adults (Zabel, 1970), and low-income single parents (Bauermeister, 1978; Joern, 1977). (2) The four factors which significantly contributed to the loneliness scores of older urban widows were length of marriage, length of widowhood, satisfaction with amount of organizational activity, and feelings about the past year. The thirteen other variables were not found to be significantly related to the population studied. (3) Older urban widows who had been married fifty years or more were significantly lonelier than those married thirty to thirty-nine years. (4) Women widowed five years or less were found to be significantly lonelier than women widowed more than five years. (5) Older urban widows who had as much organizational activity as they wanted were significantly less lonely than those who did not have as much organizational activity as they desired. (6) Older urban widows who felt happy about the past year were significantly less lonely than those who felt that the past year had been either satisfactory or unhappy. (7) Older urban widows who were lonelier were those married fifty years or more, whose husband died within the last five years, who did not have the desired amount of organizational activity, and who had been unhappy the past year.

Table No.3.Mean,SD and t-value of quality of life of widows in different age group.

\begin{tabular}{|l|l|l|}
\hline Group & $\mathbf{2 0 - 4 0}$ & $\mathbf{4 1}$ and above \\
\hline Mean & 48.08 & 60.16 \\
\hline SD & 461 & 6.29 \\
\hline $\mathbf{N}$ & 25 & 25 \\
\hline t-value & & 7.7416 \\
\hline p-value & & 0.0001 \\
\hline
\end{tabular}

The above table shows that, the Mean, SD, and t- value of widows in their quality of life, 2040and 41 and above. 20-40 widows Mean and SD is 48.08 and 461 is higher than the 41 and above widows is 60.16 and 6.29 respectively. The 20-40 widows' score indicates that, they have better quality of life of widows than the 41 and above widows. The calculate t- value is 8.54.it is significant 0.0001 level. Therefore, the formulated hypothesis is that," there is significant differences between 20-40 and 41 and above widows in these” quality of life. Hence the formulated hypothesis is accepted. Related to this research many results have found but major research mentioned here. According to "Sreerupa \& S. Irudaya Rajan (she conducted research on) Gender and Widowhood: Disparity in Health Status and Health Care Utilization Among the 


\section{Quality of Life among Widows}

Aged in India. Despite an increasing feminization of India's older population marked by a high incidence of widowhood among aged women, women's health in later life and the health consequences of widowhood has received little attention in the existing gender and gerontological scholarship in India. Based on data of a nationally representative survey by the National Sample Survey Organization ( $\mathrm{N}=34,831$, ages 60 and over), this study analyzed marital status, gender, health and health care utilization, and examined the gendered nature of aging and widowhood in India. Significant differences were found in health status and utilization of health care services by gender and marital status. Widowed persons of either gender were found to be the most vulnerable and, overall, widows emerge as the most disadvantaged group. Parkes, Murray C. MD, MRCPsych; Brown, R. J. BSc Health after Bereavement: A Controlled Study of Young Boston Widows and Widowers. Structured interviews were carried out with 49 widows and 19 widowers under the age of 45 who had been bereaved 14 months previously. A number of indices of health and emotional disturbance were shown to distinguish these bereaved respondents from a matched control group. The 13-month-bereaved group was characterized by recent disturbance of sleep, appetite and weight, by complaints of depression, restlessness, indecisiveness and sense of strain and by an increased consumption of alcohol, tobacco and tranquilizers. They were more likely than the control group to have been admitted to a hospital during the preceding year. Widowers reported an increase in acute physical symptoms although neither sex had more chronic physical symptoms than the controls. Two to four years later there was little difference in health between bereaved and control groups but there was evidence of persisting "disengagement."

Table No.4.Mean,SD and t-value of quality of life of widows in Working and non working .

\begin{tabular}{|l|l|l|}
\hline Group & Working & Non-working \\
\hline Mean & 61.64 & 46.80 \\
\hline SD & 4.61 & 2.53 \\
\hline N & 25 & 25 \\
\hline t-value & \multicolumn{2}{|c|}{14.04} \\
\hline p-value & \multicolumn{2}{|c|}{0.0001} \\
\hline
\end{tabular}

The above table shows that the Mean, SD, and t- value of widows in their quality of life. Working and None working widows Mean and SD is 61.64 and 4.61 is higher than the Non working 46.80and2.53 respectively. The Working score indicates that, they have better quality of life of widows then the Non working widows. The calculate t-value is 14.04 it is significant 0.0001 level. Therefore, the formulated hypothesis is that," there is significant differences between Working and Non-working widows in these” quality of life. Hence the formulated hypothesis is accepted. Related to this research many results have found but major research mentioned here. According to "VANISRI, SHIVAKUMAR S. CHENGTI (she conducted research) Mental Health of working and nonworking widows (2015). The aim of the present study was the mental health of working and nonworking widow, The objectives of the study 


\section{Quality of Life among Widows}

were 1) to examine the significant difference in mental health between rural and urban sample, The sample consisted 120 (60 working and 60 nonworking) selected from Gulbarga district in Karnataka state. The sample is matched for the type category of widows and domicile, the sample was administered with mental health in t-test, the result revealed that there is a significant difference in mental health between working and nonworking widows.

VANISRI;MALI PATIL,K,S; CHENGTI,SHIVAKUMARS,(she conducted research) Anxiety and social support working and nonworking widows(2012).The main purpose of the present study was to study the anxiety and social support of working and nonworking widows. The objectives of the study were 1) to examine the significant difference in anxiety between working and nonworking widows 2) to examine the significant difference in social support between working and non working widows. The sample consisted of 120 (60 working and nonworking widows) selected from Gulbarga district in Karnataka state, personal data sheet , comprehensive anxiety test (Sinhas,) and P.G. ,social support questionnaire (Ritunehra .at all.) were used to collect the required data, And the date were subjected the t-test, The result revealed that there is a significant difference in anxiety social support between working and nonworking widows samples. There was more anxiety in nonworking widows the working widows have high social support than the nonworking widows.

\section{SUMMARY AND CONCLUSION}

$>$ There is significant differences between literate and illiterate widows are their quality of life.

$>$ The literate widow's score indicates that, they have better quality of life than the illiterate widows.

$>$ There is significant difference between Rural and Urban widows is their quality of life.

$>$ The Rural widow's score indicates that have better quality of life than the Urban widows.

$>$ There is significant differences between different age group widows are their quality of life.

$>$ The 20-40 age group widows score indicates that they have better qualities of life of widows than the 41 and above widows.

$>$ There are significant differences between working and nonworking widows quality of life.

$>$ The working widow's score indicates that have better quality of life than the nonworking widows.

\section{REFRENCE}

Barret C,J; "women in widowhood in scions," the jornal of women in culture and society-1976,p $\mathrm{p}, 856$,

Behrendt, Stephen C. "Women without Men: Barbara Hofland and the Economics of Widowhood." Eighteenth Century Fiction 17.3 (2005): 481-508. Academic Search Complete. EBSCO. Web. 14 Sept. 2010. 


\section{Quality of Life among Widows}

Behrendt, Stephen C.(2005) "Women without Men: Barbara Hofland and the Economics of Widowhood." Eighteenth Century Fiction 17.3 Page NO- 481-508. Academic Search Complete. EBSCO. Web. 14 Sept. 2010.

Carr, D., House, J. S., Wortman, C. B., Nesse, R., \& Kessler, R. C. (2001). A self-care and health education program for older widows and widowers .PG (NO 615-620) vol-39 Publication (1999).

Carroll, Lucy (2008). "Law, Custom, and Statutory Social Reform: The Hindu Widows' Remarriage Act of 1856". In Sumit Sarkar, Tanika Sarkar (editors). Women and social reform in modern India: a reader. Indiana University Press. p. 78. ISBN 978-0-25322049-3. Retrieved 31 August 2011.

Chakraborty, Uma (2003). Gendering caste through a feminist lens. Popular Prakashan. p. 125. ISBN 978-81-85604-54-1. Retrieved 31 August 2011.

Cherlin, A. (1981). Marriage, divorce and remarriage. Cambridge, MA: Harvard University Press. Costa, P. T., \& McCrae, R. R. (1985). The neo personality inventory manual. Odessa, FL: Psychological Assessment Resources.

Crooks, and stein (1988); psy, science, behavior and life, New York; Holt, Reinceheart and minstan, Inc,

Dale E. Mcniel 1988 family survivors of suicide on Accidental Death; consequence for widows.VOL 18 Publication-30 DCE (2010)

Ferraro, K. F. (1984). Widowhood and social participation in later life: Isolation or compensation? Research on Aging,Vol-6(4),PgNo-451468

Forbes, Geraldine (1999). Women in modern India. Cambridge University Press. p. 23. ISBN 978-0-521-65377-0. Retrieved 31 August 2011.

Lamamudra; “ The plight of widows "social wealfare Feb-March 1986, pp,13,

Owen, Margaret. A World of Widows. Illustrated. Atlantic Highlands, NJ: Zed Books, 1996. 181-183. eBook.

Peers, Douglas M. (2006). India under colonial rule: 1700-1885. Pearson Education. ISBN 9780-582-31738-3. Retrieved 31 August 2011.

Shirley L.O. Bryant (Feb 1988), Jounal of marriage and family Siblings support and older widows well-Being. Pg No 173-183, VOL-50,

Vanisri, shivakumar s. Chengti (2015), Mental health of working and nonworking widows. Indian streams Research Jornal,vol,v,Issue, I, DOI; 10,9780\22307850, http:// isri, org/Uploaded Date/5973,pdf. 